\author{
NATALIA KOWALCZYK ${ }^{1}$, ANETA BRZEZICKA ${ }^{1,2}$ \\ ${ }^{1}$ Instytut $i$ Wydzial Psychologii \\ SWPS Uniwersytet Humanistycznospoleczny \\ Chodakowska 19/31, 03-815 Warszawa \\ ${ }^{2}$ Cedars-Sinai Medical Center \\ 8700 Beverly Blvd, Los Angeles, CA 90048, USA \\ E-mail: nkowalczyk2@gmail.com \\ Aneta.Brzezicka@cshs.org
}

\title{
GRY WIDEO A ZMIANY STRUKTURALNE MÓZGU
}

\section{WSTEP}

Historia gier komputerowych sięga lat 80. ubiegłego wieku. Od tego momentu ich rozwój trwa nieprzerwanie, gry stały się we współczesnej kulturze jedna $\mathrm{z}$ dominujacych form codziennej rozrywki. Sprzedaż gier wideo w Stanach Zjednoczonych wyniosła w 2018 r. około 43,5 miliardów dolarów. Według raportu Nielsen $360^{\circ}$ Gaming Report gracze spędzaja obecnie o $12 \%$ więcej czasu grając w gry, niż w 2012 r. Średnio graja ponad 6 godzin w trakcie przeciętnego tygodnia. We współczesną grę wideo można grać przy użyciu różnych platform, w tym komputerów osobistych, dedykowanych konsoli do gier, a także urządzeń przenośnych (tabletów, laptopów i smartfonów). Należy również wspomnieć, iż według statystyk, przeciętny gracz ma średnio 33 lata, a większość graczy stanowią mężczyźni (ponad 54\%) (ENTERTAINMENT SOFTWARE ASSOCIATION 2019).

Pomimo iż komercyjne gry wideo nie zostały zaprojektowane $\mathrm{w}$ celu trenowania poszczególnych zdolności poznawczych, to w ciagu ostatnich dwóch dekad wiele ważnych prac koncepcyjnych i empirycznych poszerzyło wiedzę na temat zmian behawioralnych kryjących się za poprawa funkcjonowania poznawczego $\mathrm{w}$ wyniku doświadczeń $\mathrm{z}$ grami komputerowymi. Szczególnym zainteresowaniem objęte zostały tzw. ,action video games", czyli gry akcji. Jest to zróżnicowany gatunek gier, obejmujący zarówno gry strategiczne czasu rzeczywistego (ang. real time strategy games, RTS), jak i gry zręcznościowe (tzw. strzelanki, ang. first person shooters games, FPS). Niezależnie od szczegółowych rozwiązań stosowanych przez poszczególnych producentów, gry akcji łączy, z perspektywy psychologicznej, szereg istotnych cech. Wszystkie one wymagaja od graczy bardzo wysokiego poziomu zaangażowania szeregu procesów poznawczych: od podstawowych procesów percepcyjnych, takich jak zdolności do monitorowania szybko poruszających się przedmiotów, poprzez utrzymywanie uwagi i odpowiedniego poziomu czujności, aż po bardziej złożone aspekty naszego funkcjonowania zwiazane $z$ działaniem pamięci operacyjnej, takie jak odświeżanie informacji, przełączanie się pomiędzy różnymi zadaniami czy ich planowanie. Oznacza to, że, być może wbrew stereotypowym opiniom, granie $\mathrm{w}$ gry komputerowe angażuje nie tylko zdolności percepcyjno-ruchowe, ale także wiele złożonych funkcji poznawczych i kontrolnych.

\section{WPEYW GIER KOMPUTEROWYCH NA ZDOLNOSCI POZNAWCZE}

Praca przeglądowa Bediou i współaut. (2018) podsumowuje doniesienia na temat wpływu grania w gry akcji na różne funkcje poznawcze, zarówno $z$ punktu widzenia

Slowa kluczowe: gry wideo, neurobrazowanie, zmiany strukturalne mózgu

*Praca finansowana ze środków Narodowego Centrum Nauki przyznanych na podstawie decyzji numer: UMO-2016/23/B/ HS6/03843. Pierwsza autorka publikacji jest stypendystka korzystająca ze wsparcia finansowego Fundacji na rzecz Nauki Polskiej (FNP), oraz Fundacji Kościuszkowskiej (Kosciuszko Foundation). 
(A)

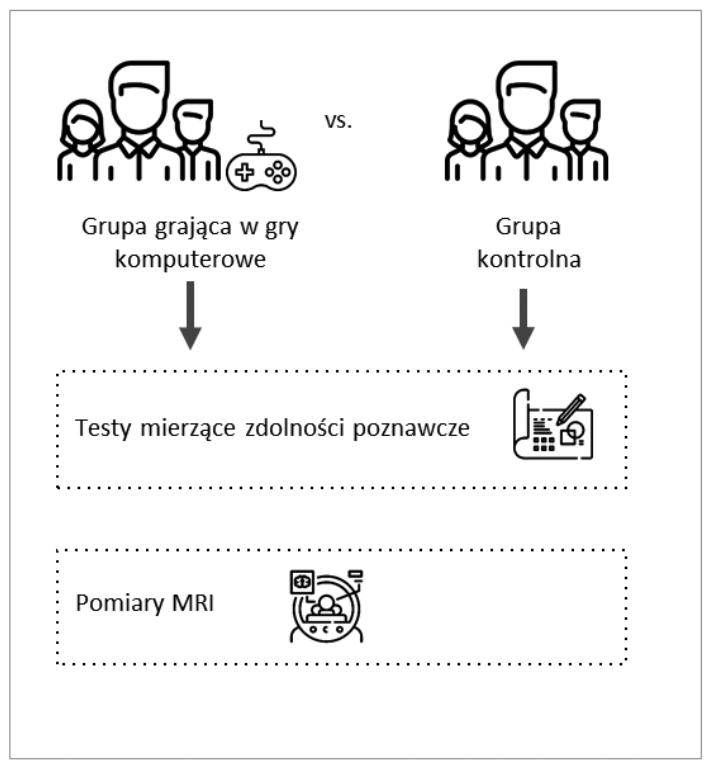

(B)

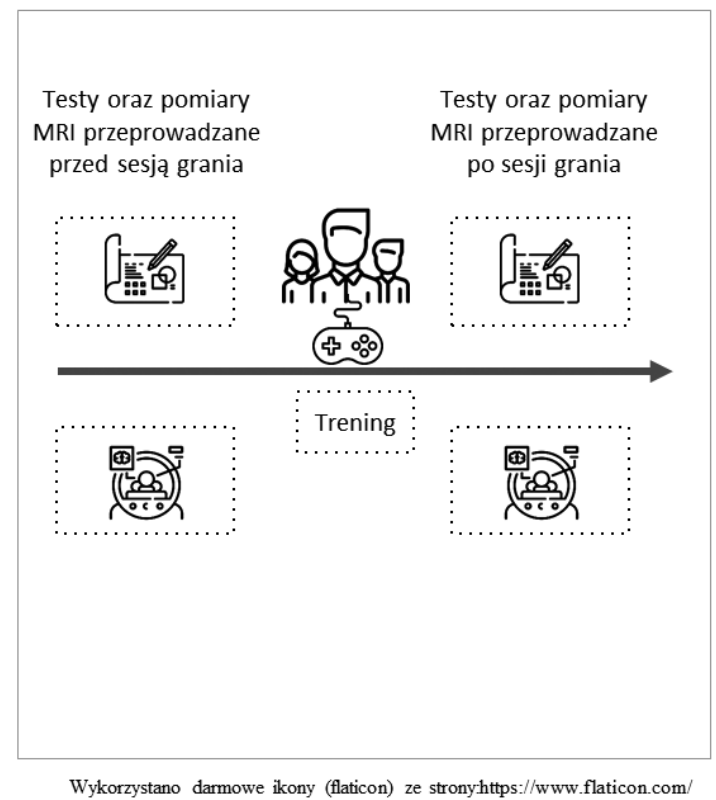

Ryc. 1. Schematyczne przedstawienie paradygmatów badawczych wykorzystywanych w badaniu procesów neuroplastyczności w wyniku doświadczenia $z$ grami komputerowymi.

(A) - schemat badań różnicowych, (B) - schemat badań podłużnych. Przedstawione paradygmaty sa wersjami podstawowymi. W badaniu różnicowym można porównywać więcej niż dwie grupy, natomiast w badaniach podłużnych można dodać dodatkowe punkty pomiaru oraz dodatkowa grupe (eksperymentalną - trenująca inne zadanie, lub pasywną - nietrenująca). Wykorzystano darmowe ikony (flaticon) ze strony:https://www.flaticon.com/

badań ekspertów, jak i badań interwencyjnych wykorzystujaccych gry jako specyficzne treningi poznawcze (Ryc. 1). W wielu badaniach informowano o sprawniejszym działaniu złożonych funkcji poznawczych, takich jak kontrola poznawcza, zdolność do przełączania się pomiędzy zmieniającymi się zadaniami/regułami, czy odświeżanie informacji w pamięci krótkotrwałej w wyniku doświadczenia $z$ grami akcji.

W kilku badaniach zaobserwowano pozytywny wpływ intensywnego grania na kontrolę uwagi typu góra-dół (czyli aktywny charakter spostrzegania, w którym dużą rolę odgrywaja wcześniej utworzone w pamięci reprezentacje, wykorzystywane przez osobę $\mathrm{w}$ celu interpretacji i klasyfikacji postrzeganego przedmiotu) (CHISHOLM i KINGSTONE 2012, GREEN i BAVELIER 2012), czy kontrolę wykonawcza (STROBACH i współaut. 2012, OEI i PATTERSON 2013). Co więcej, gracze, w porównaniu $z$ osobami nie grajacymi, lepiej wypadali w zadaniach mierzacych zdolności do przełaczania się między zmieniajacymi się wymogami czy regułami (COLZATO 2010, GREEN i współaut. 2012). Wyniki kolejnych eksperymentów wykazały również pozytywny wpływ korzystania $z$ gier akcji, przede wszystkim w przypadku graczy FPS, na funkcjonowanie pamięci roboczej (COL-
ZATO i współaut. 2013). MiSHRA i współaut. (2011) wykazali, że gracze, w porównaniu $z$ osobami nie grajacymi, lepiej radza sobie $z$ hamowaniem informacji rozpraszajacych. Pośród wielokrotnie zreplikowanych wyników widzimy natomiast te wskazujace, że gracze, w porównaniu $z$ grupa kontrolna, sa sprawniejsi w zakresie bardziej podstawowych zdolności poznawczych. Na przykład zespół BAVELIER i współaut. (2012) wykazał, że osoby grajace efektywniej filtruja informacje rozpraszajace $w$ paradygmacie mierzacym dystrybucję uwagi wzrokowej. Osoby te przejawiaja również, zwiększone pole uwagi (GREEN i BAVELIER 2003, 2006a; FENG i współaut. 2007). W niektórych badaniach pokazano, że gry komputerowe moga wywierać pozytywny wpływ również na takie zdolności jak: pamięć krótkotrwała (BLACKER i Curby 2013, WILMs i współaut. 2013), jednoczesne śledzenie wielu obiektów (GREEN i BAVELIER 2006b, Sungur i Boduroglu 2012) oraz bardziej efektywne przeszukiwanie pola wzrokowego (CASTEL i współaut. 2005), lepszą przestrzenną rozdzielczość widzenia (CASTEL i współaut. 2005, GREEN i BAVELIER 2007), czy wykrywanie istotnych zmian w kierunku ruchu obiektu (WEST i współaut. 2008). Bardziej podstawowe aspekty percepcji, takie jak ogólne skrócenie percepcyjnych 
czasów reakcji (DYE i współaut. 2009a, b) i zwiększona wrażliwość na kontrast, również ulegaja poprawie w wyniku doświadczenia $z$ grami komputerowymi (LI i współaut. 2009). Pomimo imponujacej liczby badań, które wykazały poprawę wyników, w literaturze odnaleźć można również doświadczenia, które nie ujawniły różnic między grającymi i nie grającymi w gry, w wykonaniu testów mierzacych zdolności poznawcze. W szczególności, części badaczy nie udało się powtórzyć efektów poprawy działania pamięci roboczej (Bоot i współaut. 2008, 2010, 2011; BOOT i SimONs 2012; UnsworTh i współaut. 2015) oraz lepszego hamowania informacji rozpraszających (MURPHY i SPENCER 2009, IRONS i współaut. 2011, MCDERMOTT i współaut. 2014) w wyniku doświadczenia $z$ grami. Wyniki te sa w sprzeczności $z$ wieloma badaniami, które sugeruja silny związek między doświadczeniem w grze a zdolnościami poznawczymi.

Warto podkreślić, że usprawnienia w przetwarzaniu informacji wzrokowych zaobserwowano nie tylko u osób zdrowych, ale także u pacjentów $z$ uszkodzonymi funkcjami wzrokowymi. Li i współpracownicy (2011) wykazali, że pacjenci $z$ niedowidzeniem znacznie poprawili się w szerokim zakresie podstawowych funkcji widzenia, takich jak ostrość widzenia i lepsza koncentracja uwagi, już po krótkim szkoleniu $z$ użyciem gier wideo. Ponadto, BEJJANKI i współaut. (2014) wskazali, że gry akcji poprawiaja wydajność w zadaniu identyfikacji wzorców przy różnych poziomach zewnętrznych informacji zakłócających i zaproponowali model, w którym usprawnieniu funkcji towarzyszyła wydajniejsza łączność między obszarami wzrokowymi mózgu. Wyniki te potwierdzono również w metaanalizach. Na przykład, POWERS i współaut. (2013) zestawili wyniki zarówno badań treningowych, jak i różnicowych (gdzie porównują doświadczonych graczy i osoby niemajace kontaktu $z$ grami) i pokazali pozytywny wpływ grania w gry komputerowe na funkcje poznawcze. Pomimo iż badania w tym obszarze prowadzone sa od 2003 r., trudno jest określić jednoznaczny profil zmian poznawczych powstajacych w wyniku doświadczenia $z$ grami. Aby sformułować jednoznaczna tezę na temat wpływu gier komputerowych na zdolności umysłu, potrzebne sa jeszcze kolejne badania, które uwzględniałby ocenę na wielu poziomach zachowania, czyli zarówno w warunkach laboratoryjnych, jak i w codziennym życiu. Skoro granie w gry komputerowe sprzyja uczeniu się, to powinno również propagować zdolności przydatne w codziennym życiu, w sytuacjach, które wymagaja błyskawicznych reakcji (np. podczas jazdy samochodem, gdy trzeba wykazać się silną koncentracją i refleksem). Ponadto, należy również rozważyć, czy nie jest tak, iż gry komputerowe (zwłaszcza gry akcji) przyciągają osoby, które charakteryzuja się unikatowymi umiejętnościami koncentracji, pamięci czy elastyczności w przełaczaniu się pomiędzy zadaniami.

\section{NEURONALNE KORELATY GRANIA W GRY KOMPUTEROWE}

Jak zostało przedstawione w poprzednim rozdziale, ocena wpływu gier komputerowych na zachowanie jest w ostatnich latach przedmiotem wielu badań eksperymentalnych, prac przeglądowych i metaanaliz. Znacznie mniej wiadomo natomiast o neuronalnym podłożu tych relacji.

Teoria, że struktura ludzkiego mózgu może być modyfikowana przez nowe doświadczenia, w tym gry komputerowe, stała się możliwa do weryfikacji m. in. dzięki rozwojowi techniki obrazowania rezonansem magnetycznym (MRI). Obrazowanie MRI jest preferowana technika obrazowania strukturalnych wskaźników charakterystycznych dla procesów plastyczności mózgu, dzięki wysokiej rozdzielczości przestrzennej tej metody (TARDIF i współaut. 2016). Miarami najczęściej stosowanymi w badaniach MRI sa objętość lub grubość kory mózgowej, a także gęstość mikrostruktury istoty białej, mierzone dla całego mózgu lub jego poszczególnych obszarów (regionów zainteresowania). Badania przekrojowe i podłużne wskazuja na to, iż zmiany strukturalne w wyniku różnego rodzaju doświadczenia można zmierzyć za pomoca morfometrii bazującej na wokselach (VBM), czyli ilościowej, zautomatyzowanej metody analizy strukturalnych obrazów mózgu pozwalającej w precyzyjny sposób ustalić objętość istoty szarej w części mózgu, która nas interesuje, czy obrazowania tensora dyfuzji (DTI), czyli metody pozwalajacej na zbadanie uporzadkowania włókien nerwowych oraz stopnia ich mielinizacji (DRAGANSKI i MAY 2008, JÄNCKE 2009, LÖVDÉN i współaut. 2010, 2013). Za podłoże neurobiologiczne zmian strukturalnych mózgu w wyniku doświadczenia przyjmuje się najczęściej zmiany $w$ poziomie mielinizacji aksonów, czyli zarówno zmianę liczby aksonów, ich średnicy, jak i gęstości upakowania (SAMPAIO-BAPTISTA i JOHANSEN-BERG 2017). Często opisuje się również zmiany trajektorii aksonów, neurogenezę, angiogenezę (tworzenie lub rozrost naczyń włosowatych), rozrost kolców dendrytycznych, proliferację komórek glejowych czy synaptogenezę (formowanie się połączeń między komórkami nerwowymi) (DRAGANSKI i MAY 2008, SchOlz i współaut. 2009). Coraz większa liczba badań $z$ wy- 
korzystaniem metod obrazowania struktury mózgu notuje znaczace zmiany w istocie szarej i białej mózgu w wyniku różnego rodzaju treningu funkcji poznawczych u ludzi, a doniesienia te wydają się być spójne $z$ badaniami nad zależna od doświadczenia plastycznościa u zwierząt (DRAGANSKI i MAY 2008, Mishra i GAZZALEY 2016).

Dowody na skuteczność różnych metod treningowych pochodza zarówno $z$ badań różnicowych, jak i podłużnych. Badania prowadzone w schemacie podłużnym dostarczaja najsilniejszych dowodów na zmiany zwiąane $z$ treningiem/doświadczeniem, ponieważ są one manipulowane w sposób kontrolowany, a zmiany w mózgu obserwowane przed i po uczeniu, u tej samej osoby czy zwierzęcia. W przypadku badań różnicowych nie jest możliwe ustalenie, czy to dana charakterystyka mózgu predysponuje do określonych zachowań/rezultatów, czy różnice strukturalne wynikaja $z$ doświadczenia wywołujacego plastyczne zmiany (MAY 2011). Należy jednak podkreślić, iż literatura przedmiotu obfituje $\mathrm{w}$ badania neuroanatomiczne, w których wyniki ekspertów $z$ różnych dziedzin, w tym również graczy gier komputerowych, sa porównywane do wyników badanych $z$ grupy kontrolnej (bez specyficznego doświadczenia) (GASER i ScHLAUG 2003, HÄNGGI i współaut. 2009, WEI i współaut. 2011). Badania w tym nurcie opieraja się na założeniu, że intensywna praktyka/nauka nowych umiejętności powoduje zmiany specyficznych regionów mózgu, a owe zmiany moga zostać zauważone właśnie poprzez porównanie wyników ekspertów uczestników Z grupy kontrolnej.

W 2017 r. PALAUs i współaut. opublikowali systematyczny przegląd badań sprawdzających wpływ gier komputerowych na mózg człowieka. Uwzględnili w nim wyniki eksperymentów badajacych zmiany struktur mózgu, ale również ich aktywności funkcjonalnej (badania $z$ wykorzystaniem funkcjonalnego rezonansu magnetycznego, fMRI), jak i elektrycznej (badania $z$ wykorzystaniem elektroencefalografii, EEG). W kolejnej części artykułu przedstawiamy najważniejsze doniesienia o wpływie gier na strukturę mózgu na poziomie istoty szarej $i$ istoty białej mózgu.

Intensywne używanie gier komputerowych skutkuje większa grubością kory (mierzonej przy użyciu morfometrii bazującej na wokselach, VBM) w obszarach kluczowych dla procesów nawigacji przestrzennej, pamięci roboczej i planowania (głównie hipokamp i grzbietowobocznej części kory przedczołowej) (KüHn i GaLlinat 2014). Co więcej, w badaniu tym wykazano również dodatnia korelację pomiędzy objętościa istoty szarej w okolicach hipokampa, kory śródwęchowej oraz kory potylicznej $z$ długościa grania w gry komputerowe. Zwiększona objętość istoty szarej odnotowano również w tylnych obszarach kory potylicznej, czyli obszaru kluczowego dla działania, m.in. procesów wzrokowo-przestrzennych (TANAKA i współaut. 2013). Objętości istoty szarej w okolicach kory przedczołowej, móżdżku, zakrętu zaśrodkowego, przedniej kory zakrętu obręczy oraz grzbietowo-boczna części kory przedczołowej były dodatnio skorelowane $z$ poprawa umiejętności w grze typu RTS (BASAK i współaut. 2011). Porównując doświadczonych graczy gier akcji $z$ amatorami wykazano również zwiększona objętość istoty szarej w części kory wyspy, czyli obszaru mózgu ważnego dla funkcji uwagi i funkcji czuciowo-ruchowych (GoNG i współaut. 2015). W grupie graczy gry strategicznej zaobserwowano przyrost objętości istoty szarej $\mathrm{w}$ regionie prawego zakrętu czołowego górnego, zakrętu ciemieniowego górnego oraz prawego zakrętu przedśrodkowego, i co więcej, objętość okolic czołowych korelowała dodatnio $z$ długościa kariery gracza i jakościa wykonania zadania na kontrolę poznawcza (HYUN i współaut. 2013). Co więcej, wykazano również, iż pewne wrodzone różnice indywidualne anatomii mózgu takie jak, np. wielkość prązkowia, przewiduja powodzenie w grze strategicznej typu Space Fortress (ERICKSON i współaut. 2010).

Zmiany w strukturze mózgu w wyniku intensywnego używania gier komputerowych zaobserwowano również $\mathrm{w}$ badaniach $z$ użyciem metody DTI. Okazało się, że osoby $z$ takim doświadczeniem miały podwyższony wskaźnik anizotropii frakcjonowanej (ang. fractional anisotropy, FA), co wskazuje na większa „spoistość" istoty białej w przednich obszarach mózgu (głównie przedniej części zakrętu obręczy, prawego górnego i dolnego zakrętu czołowego), jak również w okolicach wzgórza, czyli w obszarach zawierajacych połaczenia zwiazane $z$ uwaga, pamięcia robocza oraz procesami kontroli wykonawczej (LEE i współaut. 2010). Zespół Zhanga (ZHANG i współaut. 2015) wykazal, iż doświadczeni gracze gier komputerowych mają zwiększoną integralność istoty białej w okolicach kory ruchowej i potylicznej, w porównaniu $z$ osobami kontrolnymi. W jednym $z$ badań wykazano również zwiększoną strukturalna łączność między czołowymi i potylicznymi regionami w grupie graczy gier strategicznych czasu rzeczywistego (KIM i współaut. 2015). Wyniki naszego zespołu wskazały na zwiększona liczbę połaczeń strukturalnych między regionami ciemieniowymi a potylicznymi w grupie graczy gier RTS, w porównaniu do osób niegrajacych 
(KowALCZYK i współaut. 2018). Tylko jedno badanie pokazało dotychczas, że doświadczenie $z$ grami akcji zwiazane jest ze zmienionymi połaczeniami istoty białej w sieciach przedczołowych, układzie limbicznym i sieciach czuciowo-ruchowych, które sa zwiazane $z$ kontrola poznawcza i funkcjami czuciowo-ruchowymi (GONG i współaut. 2017). Już w wyniku 15 min. treningu $z$ gra strategiczna zaobserwowano większa integralność istoty białej w lewym hipokampie, natomiast w wyniku doświadczenia $z$ gra typu "strzelanka" zaobserwowano zmiany w okolicach sklepienia i prązka krańcowego (RAY i współaut. 2017).

Przedstawione powyżej doniesienia literaturowe nie przedstawiaja spójnego wzorca zmian neuronalnych wywołanych doświadczeniem $z$ grami komputerowymi. Najczęściej raportowane $\mathrm{w}$ badaniach sprawdzajacych różnice w objętości istoty szarej mózgu obejmowały głównie obszary grzbietowo-bocznej kory przedczołowej, górne i tylne obszary kory ciemieniowej, przednią część kory zakrętu obręczy, móżdżek, korę wyspy, jądra podstawne (w tym prażkowie) i hipokamp. PALAUS i współaut.(2017) w pracy przeglądowej podkreślają, iż jeszcze mniej spójne wydają się być wnioski $z$ badań na poziomie mikrostrukturalnym istoty białej, opisujace zmiany w pęczkach włókien łączących: m.in. obszary kory przedczołowej, wzrokowej, ruchowej, skroniowej, ciała modzelowatego, wzgórza asocjacyjnego, torebki zewnętrznej i w obrębie jacder podstawy.

Jednym $z$ wyjaśnień braku spójnego wzorca zmian strukturalnych może być fakt, iż tylko w części $z$ opisywanych badań kontrolowano gatunki gier, w które grali uczestnicy. Pozostali badacze umieszczali wszystkie gatunki w jednej kategorii - gier akcji. Co więcej, nie brano pod uwagę poziomu umiejętności uczestników. Ostatnie odkrycia podkreślają, że ważne jest uwzględnianie wyżej wymienionych zmiennych w przeprowadzanych eksperymentach (LATHAM i współaut. 2013; OEI i PATTERSON 2013, 2015; DOBROWOLSKI i współaut. 2015). Wartościowe byłoby również sprawdzenie, jak długo utrzymuja się zmiany w mózgu w wyniku doświadczenia $z$ grami, czyli czy sa to zmiany trwałe oraz czy uzyskane efekty słabna wraz $z$ upływem czasu.

SZYBKO I INTENSYWNIE, CZYLI GRY KOMPUTEROWE JAKO SPOSÓB POBUDZANIA NEUROPLASTYCZNOSCI

Funkcjonujaca obecnie definicja neuroplastyczności jest bardzo szeroka. Obejmuje ona trwałe zmiany siły połączeń między komórkami nerwowymi, zachodzace pod wpływem działania bodźców ze środowiska lub uszkodzenia układu nerwowego (KossuT 2018). Dzięki niej możliwa jest nie tylko odbudowa funkcji, ale również uczenie się. W tym miejscu należałoby również zastanowić się co sprawia, że gry promuja neuroplastyczność. W neuronauce behawioralnej paradygmat „wzbogaconego środowiska” (ang. enriched environment), czyli zwiększanie stymulacji zmysłowej, ruchowej i poznawczej jest bardzo często przywoływany w kontekście promowania procesów neuroplastyczności. W życiu codziennym istnieje wiele, „wzbogacających" aspektów, ponieważ codziennie dostosowujemy się do nowych doświadczeń i sytuacji w środowisku, lecz nie wszystkie $z$ nich powoduja zmiany w mózgu. $Z$ teoretycznego punktu widzenia, gry komputerowe można uznać za rodzaj wzbogaconego środowiska, które zapewnia użytkownikom stymulujące i złożone bodźce przy okazji dostarczając odpowiedniej motywacji do zaangażowania w proponowane przez nie czynności.

Już latach 40. XX w. Donald Hebb zauważył, iż szczury żyjące $\mathrm{w}$ jego domu jako zwierzęta domowe, miały lepsze zdolności poznawcze niż szczury trzymane $\mathrm{w}$ standardowych klatkach laboratoryjnych. Badania na modelach zwierzęcych wskazuja, że wzbogacone środowisko stymuluje procesy plastyczności mózgu wyrażające się zwiększeniem liczby kolców dendrytycznych, tworzeniem nowych połączeń synaptycznych, modulacja procesów neurotransmisji, zwiększeniem wielkości neuronów, czy zwiększeniem grubości kory mózgu (DiAmond i współaut. 1967, GLOBUS i współaut. 1973, GREENOUGH i współaut. 1973, GREEN i GREENOUGH 1986, VAN PRAAG i współaut. 2000). Najnowsze badania skupiaja się na badaniu wpływu urozmaiconego środowiska na proces neurogenezy (ClEMENSON i STARK 2015, GARTHE i współaut. 2016).

Wzbogacone środowisko, zdefiniowane jako „kombinacja złożonej nieożywionej i społecznej stymulacji" zostało również wykorzystane jako eksperymentalny paradygmat $\mathrm{w}$ badaniach na ludziach. Różne paradygmaty treningowe uznawane były za formę „wzbogacania środowiska”. Większość $z$ tych paradygmatów, opierających się na stymulacji zmysłowej, ruchowej czy poznawczej, wywoływała zmiany $\mathrm{w}$ zachowaniu, ale też zmiany na poziomie połączeń neuronalnych (VAN PRAAG i współaut. 2000). Kluczowym elementem w stosowanych reżimach treningowych okazywała się być złożoność i kompleksowość ćwiczeń. Badacze wciąż poszukuja idealnego paradygmatu treningu poznawczego. W ostatnich latach coraz częściej rozpatruje się $\mathrm{w}$ tym kontekście gry 
komputerowe. Niektóre definicje dotyczace wzbogaconego środowiska, takie jak poszukiwanie nowatorskich zajęć rekreacyjnych (SCARMEAS i współaut. 2001) i praca pod presja czasu w dynamicznie zmieniającym się otoczeniu (ScHOOLER i współaut. 1999), stanowia poparcie tego twierdzenia. Definicje te wymieniaja szereg elementów, które sa bezpośrednio obecne w grach komputerowych. Twórcy gier komputerowych, w szczególności gier akcji dbają o to, aby pojawiały się w nich nowe wyzwania, czyli aby odpowiednie poziomy gry cechowały się właściwym tempem i poziomem trudności. Interaktywne gry komputerowe stanowia bogate źródło przyjemności i chociaż nie powstały, aby edukować, promuja naukę nowych, złożonych umiejętności oraz generuja zmiany nie tylko w zachowaniu, ale i w strukturze mózgu. Należy również dodać, że gra $z$ kategorii strategii czasu rzeczywistego została wybrana przez DeepMind, światowego lidera w sztucznej inteligencji, za środowisko testowe do badań sztucznej inteligencji, ponieważ "stanowi ona odbicie rzeczywistego świata" oraz ze względu na fakt, iż wymagania stawiane przed „agentem" do osiągania celów w grze można ostatecznie przenieść do zadań stawianych w świecie rzeczywistym" (źródło: http:/ /goo.gl/cF1VcJ).

Zanim jednak gry zostały zauważone przez naukowców jako narzędzie do trenowania funkcji poznawczych, większość badaczy łaczyła je $z$ agresją i uzależnieniem (LIN i LEPPER 1987, ANDERSON i BUSHMAN 2001, FERGUSON 2011). Jednak od poczatku wnioski na temat wywoływania agresji, zwłaszcza u młodych użytkowników, nie były spójne (SHERRY 2001, ANDERSON 2010). Głos w tej debacie zabrali również członkowie Amerykańskiego Stowarzyszenia Psychologicznego APA (2015) zgłaszając swoje zastrzeżenia, co do gier wideo i ich użytkowania przez dzieci i młodzież. Część naukowców twierdzi jednak, że zwiazek gier $z$ agresja jest minimalny lub w ogóle nie istnieje (FERGUSON 2015). Większość gier, które mogłyby być skategoryzowane jako „brutalne” w kontekście debaty nad ich negatywnymi skutkami, w przypadku podkreślania ich pozytywnego wpływu na funkcjonowanie poznawcze nazywane sa już grami akcji (na przykład w literaturze dotyczacej treningów poznawczych). To zróżnicowanie użycia emocjonalnego języka podczas kategoryzacji gier może odzwierciedlać nastawienie badaczy w różnych dziedzinach.

Obecnie, gdy badacze intensywnie zgłębiaja wiedzę na temat tego, jak gry wideo usprawniaja procesy poznawcze oraz coraz intensywniej weryfikuja zmiany na poziomie struktury i wzorca aktywności mózgu w wyniku doświadczenia $z$ grami, podejmowane sa próby zastosowania zdobywanej wiedzy do opracowywania programów treningowych dla osób z uszkodzeniami mózgu czy deficytami poznawczymi. Kluczowe w tym aspekcie wydaje się dokładne dopasowanie profilu i poziomu trudności gry do potrzeb pacjentów. Jednocześnie trzeba podkreślić, iż należy nadal zachować duża ostrożność w przewidywaniu efektów wykorzystania gier w terapii. Potrzeba kolejnych, wnikliwych badań, które pozwola nam zrozumieć, jak budować narzędzia, które mogłyby być wykorzystywane przez pacjentów do wspierania procesu odbudowy funkcji ich mózgu.

Streszczenie

Mimo iż gry wideo, zwane również grami komputerowymi, nie powstały, aby uczyć, to stanowia płaszczyznę do badania neuroplastyczności, czyli zdolności mózgu do ,,przeprogramowywania się" w wyniku specyficznego doświadczenia. Badania donosza, iż regularne granie $\mathrm{w}$ gry komputerowe, w szczególności gry akcji, poprawia głównie podstawowe zdolności poznawcze, takie jak: szybkość reagowania, wrażliwość na kontrast czy selektywność i podzielność uwagi. Pojedyncze badania pokazuja poprawę funkcji wykonawczych. Mniej wiadomo natomiast na temat neuronalnych podstaw tego rodzaju poprawy. W niniejszym artykule podsumowujemy wyniki badań, w których przeprowadzano pomiary strukturalnych zmian mózgu $\mathrm{w}$ wyniku doświadczenia $\mathrm{z}$ grami komputerowymi. Zestawione zostały badania wykorzystujace głównie dwie metody badania plastyczności mózgu: morfometrii bazujacej na wokselach (ang. based morphometry, VBM) istoty szarej oraz obrazowanie tensora dyfuzji (ang. diffusion tensor imaging, DTI) $\mathrm{w}$ istocie białej. Badania zmian strukturalnych mózgu $\mathrm{z}$ użyciem rezonansu magnetycznego (magnetic resonance imaging, MRI) dostarczaja kolejnych przykładów na potencjalne korzyści płynace $z$ grania $w$ gry komputerowe.

\section{PODZIEKOWANIE}

Ikony wykorzystane w Ryc. 1 wykonane zostały przez Freepik.mynamepong.wanicon ze strony https://www.flaticon.com/.

\section{LITERATURA}

ANDERson C. A., Bushman B. J., 2001. Effects of violent video games on aggressive behavior, aggressive cognition, aggressive affect, physiological arousal, and prosocial behavior: A meta-analytic review of the scientific literature. Psychol. Sci. 12, 353-359.

ANDERSON R. P., 2010. Addiction to joint logistics - the dangers of over dependence on a joint logistics concept. Naval War Coll Newport Ri Joint Military Operations Dept.

BASAK C., VOSS M. W., ERICKSON K. I., BOOT W. R., KRAMER A. F., 2011. Regional differences in brain volume predict the acquisition of skill in a complex real-time strategy videogame. Brain Cognit. 76, 407-414.

BAVElier D., ACHTMAN R. L., MANI M., FÖCKER J., 2012. Neural bases of selective attention in action video game players. Vision Res. 61, 132-143.

Bediou B., Adams D. M., Mayer R. E., Tipton E., Green C. S., BAVELIER D., 2018. Meta-analy- 
sis of action video game impact on perceptual, attentional, and cognitive skills. Psychol. Bull. 144, 77-110.

BEJJANKI V. R., ZHANG R., Li, R., POUget A., GREEN C. S., LU, Z.-L., BAVELIER D., 2014. Action video game play facilitates the development of better perceptual templates. Proc. Natl. Acad. Sci. USA 111, 16961-16966.

Blacker K. J., Curby K. M., 2013. Enhanced visual short-term memory in action video game players. Atten. Percept. Psychophys. 75, 1128-1136.

Boot W. R., Simons D. J., 2012. Advances in video game methods and reporting practices (but still room for improvement): A commentary on Strobach, Frensch, and Schubert (2012). Acta Psychol. 141, 276-277.

Boot W. R., Kramer A. F., Simons D. J., FABIANI M., GRATTON G., 2008. The effects of video game playing on attention, memory, and executive control. Acta Psychol. 129, 387-398.

BOOT W. R., BASAK C., ERICKSON K. I., NEIDER M., SiMONS D. J., FABIANI M. i współaut., 2010. Transfer of skill engendered by complex task training under conditions of variable priority. Acta Psychol. 135, 349-357.

Boot W. R., Blakely D. P., Simons D. J., 2011. Do action video games improve perception and cognition?. Front. Psychol. 2, 226.

CASTEL A. D., PRATT, J., DRUMMOND E., 2005. The effects of action video game experience on the time course of inhibition of return and the efficiency of visual search. Acta Psychol. 119, 217-230.

Chisholm J. D., KingStone A., 2012. Improved top-down control reduces oculomotor capture: The case of action video game players. Atten. Percept. Psychophys. 74, 257-262.

Clemenson G. D., STARK C. E. L., 2015. Virtual environmental enrichment through video games improves hippocampal-associated memory. J. Neurosci. 35, 16116-16125.

COlZATO L. S., 2010. DOOM'd to switch: superior cognitive flexibility in players of first person shooter games. Front. Psychology 1, 8.

Colzato L. S., VAN Den Wildenberg W. P. M., ZMIGROD S., HOMMEL B., 2013. Action video gaming and cognitive control: playing first person shooter games is associated with improvement in working memory but not action inhibition. Psychol. Res. 77, 234-239.

DIAMOND M. C., LINDNER B., RAYMOND A., 1967. Extensive cortical depth measurements and neuron size increases in the cortex of environmentally enriched rats. J. Compar. Neurol. $131,357-364$.

Dobrowolski P., Hanusz K., SOBCzyK B., SKORKO M., Wiatrow A., 2015. Cognitive enhancement in video game players: The role of video game genre. Comput. Human Behav. 44, 59-63.

DRAGANSKI B., MAY A., 2008. Training-induced structural changes in the adult human brain. Behav. Brain Res. 192, 137-142.

Dye M. W. G., GREen C. S., BAVELIER D., 2009a. Increasing speed of processing with action video games. Curr. Direct. Psychol. Sci. 18, 321-326.

Dye M. W. G., Green C. S., Bavelier D., 2009b. The development of attention skills in action video game players. Neuropsychologia 47, 1780-1789.

ENTERTAINMENT SOFTWARE ASSOCIATION, 2019. Essential facts about the computer and video game industry. Washington, D.C: Entertainment Software Association.
ERICKSON K. I., BOOT W. R., BASAK C., NEIDER M. B., 2010. Striatal volume predicts level of video game skill acquisition. Cerebral Cortex 20, 2522-2530.

Feng J., Spence I., PRATT J., 2007. Playing an action video game reduces gender differences in spatial cognition. Psychol. Sci. 18, 850-855.

FERGUSON C. J., 2011. Video games. Encyclopedia of Adolescence, 3040-3045.

FERGUSON C. J., 2015. Online games and crime. The International Encyclopedia of Digital Communication and Society, 1-7.

Garthe A., ROEDER I., KEMPERMANN G., 2016. Mice in an enriched environment learn more flexibly because of adult hippocampal neurogenesis. Hippocampus 26, 261-271.

GASER C., SCHLAUG G., 2003. Brain structures differ between musicians and non-musicians. J. Neurosci. 23, 9240-9245.

Globus A., Rosenzweig M. R., Bennett E. L., DiAMOND M. C., 1973. Effects of differential experience on dendritic spine counts in rat cerebral cortex. J. Compar. Physiol. Psychol. 82, $175-181$

Gong D., He H., LiU D., Ma W., Dong L., LuO C., YAO D., 2015. Enhanced functional connectivity and increased gray matter volume of insula related to action video game playing. Sci. Rep. 5, 9763.

Gong D., MA W., Gong, J., HE H., DONG L., ZHANG D. i współaut., 2017. Action video game experience related to altered large-scale white matter networks. Neural Plasticity 2017, $1-7$.

Green C. S., BAVElieR D., 2003. Action video game modifies visual selective attention. Nature 423, 534-537.

GREEN C. S., BAVELIER D., 2006a. Effect of action video games on the spatial distribution of visuospatial attention. J. Exp. Psychol., Human Percept. Perform. 32, 1465-1478.

GREen C. S., BAVELIER D., 2006b. Enumeration versus multiple object tracking: the case of action video game players. Cognition 101, 217 245.

Green C. S., BAVElier D., 2007. Action-video-game experience alters the spatial resolution of vision. Psychol. Sci. 18, 88-94.

GREEN C. S., BAVELIER D., 2012. Learning, attentional control, and action video games. Curr. Biol. 22, 197-206.

Green C. S., Sugarman M. A., Medford K., KloBUSICKY E., BAVELIER D., 2012. The effect of action video game experience on task-switching. Comput. Human Behav. 28, 984-994.

Green E. J., Greenough W. T., 1986. Altered synaptic transmission in dentate gyrus of rats reared in complex environments: evidence from hippocampal slices maintained in vitro. J. Neurophysiol. 55, 739-750.

Greenough W. T., Volkmar F. R., JuRaska J. M., 1973. Effects of rearing complexity on dendritic branching in frontolateral and temporal cortex of the rat. Exp. Neurol. 41, 371-378.

HÄNGGI J., KOENEKE S., BEZZOLA L., JÄNCKE L., 2009. Structural neuroplasticity in the sensorimotor network of professional female ballet dancers. Human Brain Mapping 31, 11961206.

Hyun G. J., Shin Y. W., KIM B. N., CheOng J. H., JiN S. N., HAN D. H., 2013. Increased cortical thickness in professional on-line gamers. Psychiatry Invest. 10, 388-392.

IRONS J. L., REMINGTON R. W., MCLEAN J. P., 2011. Not so fast: Rethinking the effects of ac- 
tion video games on attentional capacity. Austr. J. Psychol. 63, 224-231.

JÄNCKE L., 2009. The plastic human brain. Restor. Neurol. Neurosci. 27, 521-538.

KIM Y.-H., H. KIM Y., -W. KANG D., KIM D., -J. KIM H., SASAKI Y., WATANABE T., 2015. Real-time strategy video game experience and visual perceptual learning. J. Neurosci. 35, 10485-10492.

KossuT M., 2018. Neuroplastyczność. Medyk Sp. $z$ oo, Warszawa

KOWALCZYK N., SHI F., MAGNUSKI M., SKORKO M., DOBROWOLSKI P., KOSSOWSKI B. i współaut. 2018. Real-time strategy video game experi ence and structural connectivity - A diffusion tensor imaging study. Human Brain Mapping 39, 3742-3758.

KÜHN S., Gallinat J., 2014. Amount of lifetime video gaming is positively associated with entorhinal, hippocampal and occipital volume. Mol. Psychiatry 19, 842-847.

LATHAM A. J., PATSTON L. L. M., TipPetT L. J., 2013. Just how expert are "expert" video-game players? Assessing the experience and exper tise of video-game players across "action" video-game genres. Front. Psychol. 4, 941.

LEe B., PARK J.-Y., JunG W. H., KIM H. S., OH J. S., CHOI C.-H. i współaut., 2010. White mat ter neuroplastic changes in long-term trained players of the game of "Baduk" (GO): a voxel-based diffusion-tensor imaging study. NeuroImage 52, 9-19.

Li R., Polat U., MaKous W., Bavelier D., 2009. Enhancing the contrast sensitivity function through action video game training. Nat. Neurosci. $12,549-551$.

Li R. W., NGo C., Nguyen J., Levi D. M., 2011. Video-game play induces plasticity in the visual system of adults with amblyopia. PLoS Biology 9, e1001135.

LIN S., LEPPER M. R., 1987. Correlates of chil dren's usage of videogames and computers. J. Appl. Soc. Psychol. 17, 72-93.

LÖVDÉN M., BodAMMER N. C., KÜHN S., KaUfMANN J., SCHÜTZE H., TEMPELMANN C. i współaut., 2010. Experience-dependent plasticity of white-matter microstructure extends into old age. Neuropsychologia 48, 3878-3883.

LÖVDÉN M., WENGER E., MÅRTENSSON J., LINDENBERGER U., BÄCKMAN L., 2013. Structural brain plasticity in adult learning and development Neurosci. Biobehav. Rev. 37, 2296-2310.

MAY A.,2011. Experience-dependent structural plasticity in the adult human brain. Trends Cognit. Sci. 15, 475-482.

MCDermotT A. F., BAVElier D., Green, C. S., 2014. Memory abilities in action video game players. Comput. Human Behav. 34, 69-78.

Mishra J., GAZZALEY A., 2016. Cross-species ap proaches to cognitive neuroplasticity research. NeuroImage $131,4-12$.

Mishra J., ZiNni M., BAVElieR D., Hillyard S. A. 2011. Neural basis of superior performance of action videogame players in an attention-demanding task. J. Neurosci. 31, 992-998.

MURPHY K., SPENCER A., 2009. Playing video games does not make for better visual attention skills. J. Artic. Support Null Hypothesis $6,1$.

Oei A. C., PATterson M. D., 2013. Enhancing cognition with video games: a multiple game training study. PloS One 8, e58546.

Oei A. C., PATterson M. D., 2015. Enhancing perceptual and attentional skills requires common demands between the action video games and transfer tasks. Front. Psychol. 6, 113.
Palaus M., Marron E. M., VIEJO-SObera R., REDOLAR-RIPOLL D., 2017. Neural basis of video gaming: A systematic review. Front. Human Neurosci. 11, 248

Powers K. L., BROOKS P. J., ALdRICH N. J., PALLADINO M. A., ALFIERI L., 2013. Effects of video-game play on information processing: a meta-analytic investigation. Psychono. Bull. Rev. 20, 1055-1079.

RAY N. R., O'CONNEll M. A., NASHIRO K., SMith E. T., QIN S., BASAK C., 2017. Evaluating the relationship between white matter integrity, cognition, and varieties of video game learning. Restor. Neurol. Neurosci. 35, 437-456.

SAMPAIO-BAPTISTA C., JOHANSEN-BERG H., 2017. White matter plasticity in the adult brain. Neuron 96, 1239-1251.

ScARMEAS N., LEVY G., -X. TANG M., MANLY J., STERN Y., 2001. Influence of leisure activity on the incidence of Alzheimer's Disease. Neurology 57, 2236-2242.

SchOlz J., KlEIN M. C., Behrens T. E. J., JohanSEN-BERG H., 2009. Training induces changes in white-matter architecture. Nat. Neurosci. 12, 1370-1371.

Schooler C., Mulatu M. S., OAtes G., 1999. The continuing effects of substantively complex work on the intellectual functioning of older workers. Psychol. Aging 14, 483-506.

SHERRY J., 2001. The effects of violent video games on aggression. A meta-analysis. Human Comm. Res. 27, 409-431.

Strobach T., Frensch P. A., Schubert T., 2012. Video game practice optimizes executive control skills in dual-task and task switching situations. Acta Psychol. 140, 13-24.

Sungur H., BODUROGLU A., 2012. Action video game players form more detailed representation of objects. Acta Psychol. 139, 327-334.

TANAKA S., IKEDA H., KasaHARA K., KaTO R., TSUBOMI H., SUGAWARA S. K. i współaut., 2013. Larger right posterior parietal volume in action video game experts: a behavioral and voxel-based morphometry (VBM) study. PloS One 8, e66998.

Tardif C. L., Gauthier C. J., Steele C. J., Bazin P.-L., SCHÄFER A., SCHAEFER A. i współaut., 2016. Advanced MRI techniques to improve our understanding of experience-induced neuroplasticity. NeuroImage $131,55-72$.

UnswORTH N., REDICK T. S., MCMILlan B. D., HAMBRICK D. Z., KANE,M. J., ENGLE R. W., 2015. Is playing video games related to cognitive abilities?. Psychol. Sci. 26, 759-774.

VAN PRAAG H., KEMPERMANN G., GAGE F. H., 2000. Neural consequences of enviromental enrichment. Nat. Rev. Neurosci. 1, 191-198.

WEI G., ZHANG Y., JIANG T., LUO J., 2011 . Increased cortical thickness in sports experts: a comparison of diving players with the controls. PloS One 6, e17112.

West G. L., Stevens S. A., Pun C., PratT J., 2008. Visuospatial experience modulates at tentional capture: evidence from action video game players. J. Vis. 8, 13.1-13.9.

WilMS I. L., PETERSEN A., VANGKILDE S., 2013. Intensive video gaming improves encoding speed to visual short-term memory in young male adults. Acta Psychol. 142, 108-118.

ZHANG Y., DU G., YANG Y., QIN W., LI X., 2015. Higher integrity of the motor and visual pathways in long-term video game players. Human Neurosci. 9, 98. 
KOSMOS Vol. 69, 1, 233-241, 2020

\author{
NATAlia KOWALCZYK ${ }^{1}$, ANETA BRZEZICKA ${ }^{1,2}$
}

${ }^{1}$ Institute and Faculty of Psychology, The University of Social Science and Humanities, 19/31 Chodakowska Str., 03-815 Warsaw, ${ }^{2}$ Cedars-Sinai Medical Center, 8700 Beverly Blvd, Los Angeles, CA 90048, USA,

E-mail: nkowalczyk2@gmail.com; Aneta.Brzezicka@cshs.org

\title{
VIDEO GAMES AND STRUCTURAL BRAIN CHANGES
}

\section{Summary}

Although the initial purpose of video games, also called computer games, was not to learn, they can be used to study neuroplasticity, i.e. brain ability to plastic reorganization after specific experience. Studies show that playing computer games regularly, especially action video games, improves basic cognitive functions, such as reaction time, contrast sensitivity or selective and divided attention. Single experiments have shown improvement in executive functions. Less is known about neural basis of such improvement. In this article we have summarized the results of studies in which structural changes in the brain as a result of video game experience were measured. We summarize results of experiments that used two methods for studying brain plasticity - voxel based morphometry (VBM) (on gray matter volume) and diffusion tensor imaging (DTI) (on white matter volume). We discuss also studies examining structural brain changes with magnetic resonance imaging technique which provide examples of possible benefits resulting from playing computer games.

Key words: neuroimaging, structural brain changes, video games 